\title{
НАУЧНОЕ НАСЛЕДИЕ ПРОФЕССОРА ЮРИЯ ДАНИЛОВИЧА ЛИФШИЦА
}

\author{
Зайцев О.А.
}

\begin{abstract}
Аннотация: Статья посвящена одному из ярких звезд отечественной юридической науки, заслуженному работнику высшей школь, доктору юридических наук, профессору Лифшииу Юрию Даниловичу. Показан его вклад в создание и развитие уголовно-процессуальной научной школь Южно-Уральского государственного университета (национального исследовательского университета). Научные идеи профессора Ю.Д. Ливщица получили свое развитие в колплексе исследований актуальных проблем развития и совершенствования российского уголовного судопроизводства, осуществляемых сотрудниками кафедры. Результатом этой деятельности стали монографии, выпущенные сотрудниками кафедры Метод или методология исследования: В процессе работы использовались общенаучные и частно-научные методы познания: диалектический, формальнологический, моделирование и структурно-функциональный. Под руководством Юрия Даниловича было подготовлено 5 докторов и более 30 кандидатов юридических наук, которые продолжают реализовывать его научные идеи. Профессор всегда был внимательным и заботливым научным руководителем для своих учеников, умел словом и делом оказать существенную поддержку. Он опекал каждого из них, максимально создавал комфортные условия для занятий наукой, вырастил не одно поколение ученых. Многие его ученики получали необходимые консультации профессора не только на работе, но и у него дома. Они стали друзьями семьи, а Юрий Данилович - добрым страшим другом и наставником для них.
\end{abstract}

Ключевые слова: Личность, безопасность, уголовно-прочессуальное право, принуждение, юриспруденция, мера пресечения, источник, эксперт, специиалист, кафедра.

Уникальный человек и масштабная личность, Юрий Данилович Лифшиц - видный ученый, крупный специалист в области уголовно-процессуального права, широко известный, как во всех бывших советских республиках, так и далеко за их пределами. Его всегда выделяли богатый опыт научно-исследовательской, преподавательской и общественной деятельности, достижения в разработке приоритетных направлений юридической науки и подготовке научно-педагогических кадров.
После окончания Алма-Атинского юридического института в 1952 году Юрий Данилович Лившиц был принят на работу в этот же ВУЗ на кафедру уголовного процесса и криминалистики в должности лаборанта - ассистента, а в 1954 году переведен на должность преподавателя. Именно с этого момента его жизнь связана с наукой уголовно-процессуального права.

С 1955 года до 1993 года Юрий Данилович работал в системе высшего и среднего образова- 
ния органов внутренних дел СССР и Казахстана, где он прошел путь от преподавателя до начальника кафедры, профессора. Мне посчастливилось испытать на себе профессиональный талант профессора в стенах Карагандинской высшей школы МВД СССР, где я сначала обучался на следственно-криминалистическом факультете, и позднее, когда стал преподавателем кафедры уголовного процесса данного ВУЗа. Для всех нас было значительным событием каждый приезд Юрия Даниловича в Караганду, возможность общения с ним. Мы с благодарностью принимали его научные мысли и идеи, с которыми он щедро делился. При этом каждому преподавателю кафедры он уделял достаточное внимание и уважение, несмотря на свою занятость.

Более пятидесяти лет своей деятельности Ю.Д. Лившиц посвятил юридической науке. Он является автором более 100 научных и учебно-методических работ, в том числе двух монографий, ставших «бестселлерами» в уголовно-процессуальной науке и не утративших актуальности до настоящего времени.

В 1959 году Ю.Д. Лившиц защитил кандидатскую диссертацию на тему «Меры процессуального принуждения в уголовном процессе» в Московском государственном университете под руководством профессора Дмитрия Сергеевича Карева. По результатам проведенного диссертационного исследования в 1964 году впервые в истории науки уголовно-процессуального права советского периода в издательстве «Юридическая литература» была издана монография «Меры пресечения в советском уголовном процессе», которая получила большой резонанс среди ученых-процессуалистов.

Заслуга Юрия Даниловича состоит в том, что эта работа одна из первых в советский период посвящена научной разработке проблем охраны прав и законных интересов личности при применении мер уголовно-процессуального принуждения. В монографии дано авторское определение

мер процессуального принуждения, как мер государственного принуждения предупредительного характера, которые, не будучи наказанием, применяются в целях осуществления задач правосудия лишь в случаях действительной к тому необходимости к субъектам уголовно-процессуальной деятельности в строгом соответствии с законом и с учетом прав и интересов этих лиц. Профессор разработал и научно обосновал систему мер пресечения, применяемых в уголовном судопроизводстве.
Актуальность данной работы не снижается до настоящего времени. Об этом свидетельствует хотя бы тот факт, что российский законодатель впервые ввел в новом Уголовно-процессуальном кодексе РФ специальный раздел, посвященный мерам процессуального принуждения.

Спустя десять лет в 1974 году выходит в свет следующая монография Юрия Даниловича Лифшица «Воспитательная функция советского уголовного судопроизводства», а в 1977 году он защищает докторскую диссертацию, посвященную теоретическим проблемам воспитательного воздействия советского уголовного процесса. Автором обосновывается предупредительновоспитательное воздействие уголовного судопроизводства. Юрий Данилович определяет воспитательную функцию как целенаправленную деятельность соответствующих субъектов уголовного процесса, регламентированную законом. Особо выделяются такие методы воспитательного воздействия, как убеждение, принуждение, приучение, поощрение. К принципам, оказывающим воспитательное воздействие, Ю.Д. Лившиц отнес законность и гласность. Повышенное внимание в работе уделено объекту воспитательного воздействия, который рассматривается как активная категория, а воспитательный процесс как взаимодействие воспитателя и воспитуемого. В монографии также показана необходимость изучения личности обвиняемого в уголовном судопроизводстве в процессуально-криминалистическом, уголовно-правовом, криминологическом и психолого-педагогическом аспектах [1].

Научные интересы профессора не были ограничены только указанными темами, которые он разрабатывал в своих диссертационных исследованиях. В научном плане и в настоящее время представляют интерес подготовленные им научные статьи. Достаточно назвать некоторые из них: «Вопросы теории доказательств и их правовая регламентация», «Независимость суда», «О суде и принципах его организации». Особо следует выделить работы, написанные в соавторстве с другими учеными-процессуалистами, например, с А.В. Кудрявцевой «Принцип законности в уголовном процессе», «Доказательственное значение «правовых» экспертиз в уголовном процессе», с С.М. Даровских «Состязательность в судебном разбирательстве: этические и психологические аспекты», «Некоторые процессуальные вопросы рассмотрения судами уголовных дел, связанных с незаконным оборотом наркотических средств», «Суд и стороны в системе доказывания в уголовном процессе России», 
с Н. В. Ткачевой «Социальная обусловленность института мер пресечения», с А.А. Дмитриевой «Понятие и признаки уголовно-процессуального представительства», с Р.А. Хашимовым «Цели в уголовно-процессуальном праве» и др.

В 1993 года профессор Ю.Д. Лившиц возглавил кафедру уголовного и гражданского права и процесса, с которой началась специальность «юриспруденция» в Южно-Уральском государственном университете (город Челябинск). Уже в 1998 году в данном учебном заведении была открыта аспирантура по специальности 12.00 .09 - уголовный процесс, криминалистика и судебная экспертиза; оперативно-розыскная деятельность, а в 2002 году начал работу диссертационный совет по защите кандидатских диссертаций по этой же специальности. Выполнение обязанностей председателя были возложены на Юрия Даниловича. Научная добросовестность Ю.Д. Лившица, его нетерпимое отношение к небрежности, халатности стали определяющими в деятельности этого диссертационного совета, который успешно действует до настоящего времени. После ухода Юрия Даниловича состав диссертационного совета и его руководство менялось, диссертационный совет возглавляли профессора А.В. Кудрявцева, В.И. Майоров, но планка высокой требовательности к качеству диссертационных исследований, поднятая Ю.Д. Лившицем, сохранена до настоящего времени.

Под руководством Юрия Даниловича было подготовлено 5 докторов и более 30 кандидатов юридических наук, которые продолжают реализовывать его научные идеи. Профессор всегда был внимательным и заботливым научным руководителем для своих учеников, умел словом и делом оказать существенную поддержку. $\mathrm{OH}$ опекал каждого из них, максимально создавал комфортные условия для занятий наукой, вырастил не одно поколение ученых. Многие его ученики получали необходимые консультации профессора не только на работе, но и у него дома. Они стали друзьями семьи, а Юрий Данилович добрым страшим другом и наставником для них.

Творческое наследие Юрия Даниловича Лившица явилось той базовой основой, на которой проводят свои научные исследования его ученики и последователи, в том числе преподаватели кафедры уголовного процесса и криминалистики Южно-Уральского государственного университета. Профессор Ю.Д. Лившиц фактически являлся научным консультантом по докторской диссертации Анны Васильевны Кудрявцевой на тему «Судебная экспертиза как институт уголов- но-процессуального права», которая блестяще была защищена в 2001 году.

Особо хотелось бы выделить следующие кандидатские диссертации, по которым научным руководителем был Юрий Данилович: «Принцип состязательности в уголовном процессе России и механизм его реализации» (С.М. Даровских), «Информационное обеспечение уголовного процесса» (С.В. Зуев), «Процессуальные и организационные вопросы отказа в возбуждении уголовного дела в уголовном процессе России» (Б.М. Сергеев). Именно профессор Ю.Д. Лифшиц проложил данным ученым путь в большую науку, что позволило им в дальнейшем защитить докторские диссертации по актуальным проблемам уголовного судопроизводства и стать профессорами.

Кроме того, следует назвать кандидатскую диссертацию Н.В. Ткачевой

на тему «Теория и практика мер пресечения, не связанных с заключением под стражу», которая в своей работе продолжила и развила идеи своего научного руководителя, Юрия Даниловича Лившица, касающиеся проблемных вопросов реализации мер пресечения.

Идеи Ю.Д. Лившица также были успешно реализованы в кандидатских диссертациях таких молодых, но перспективных ученых, как Г.С. Русман, А.А. Русман, Р.А. Хашимов, С.В. Тетюев, В.С. Вепрев, с которыми профессор начинал работать как научный руководитель. Любовь Юрия Даниловича к своей профессии поражала, а его авторитет настолько значим, что это сказалось на выборе профессии его учениками. Многие из них (Н.В.Ткачева, Г.С. Русман, Р.А. Хашимов, С.В. Тетюев и др.) после защиты кандидатских диссертаций работают преподавателями, в том числе и на кафедре уголовного процесса и криминалистики ЮжноУральского государственного университета. Они являются продолжателями творческого наследия профессора Ю.Д. Лифшица, ведут активную научную работу, выступают рецензентами и оппонентами по кандидатским диссертациям, публикуют научные статьи, монографии, учебные пособия и активно работают со студентами, приобщая их к научной деятельности.

Следует отметить, что основной состав кафедры, сформированный еще при Ю.Д. Лившице, практически не менялся. Особая заслуга в этом профессора Анны Васильевны Кудрявцевой, ученицы Юрия Даниловича, которая эффективно руководила кафедрой более 7 лет, успешно возглавляла диссертационный совет, обеспечивая качество его работы, руководила кандидатскими 
диссертациями, в том числе и тех аспирантов, с которыми начинал работать Юрий Данилович. Благодаря профессиональному таланту и человеческим качествам профессора А.В. Кудрявцевой, во многом поддерживаются добрые традиции, которые зарождал на кафедре и факультете профессор Ю.Д. Лифшиц. Анна Васильевна убедительно показывает научной общественности значение трудов и всей деятельности Ю.Д. Лифшица для развития современного уголовно-процессуального права и других наук [2]. При ее непосредственном участии были изданы избранные труды Юрия Даниловича.

Научные идеи профессора Ю.Д. Лившица получили свое развитие в комплексе исследований актуальных проблем развития и совершенствования российского уголовного судопроизводства, осуществляемых сотрудниками кафедры. Результатом этой деятельности стали монографии, выпущенные сотрудниками кафедры: «Меры пресечения, не связанные с лишением свободы в уголовном процессе России» (Н.В. Ткачева), «Прекращение уголовного дела в связи с примирением сторон на стадии предварительного расследования» (Л.В. Виницкий, Г.С. Русман, А.А. Русман), «Внутреннее убеждение как основание свободы оценки доказательств» (О.Е. Яцишина), «Актуальные вопросы методики расследования краж цветных металлов» (Т.И. Ястребова), «Специальные знания в уголовном процессе России» (И.И.Трапезникова), «Правовые позиции Конституционного Суда РФ, касающиеся реализации принципа состязательности в уголовном судопроизводстве» (С.М. Даровских), «Получение образцов для сравнительного исследования в уголовном судопроизводстве России»
(А.В.Кудрявцева, Ю.А.Кудрявцева), «Злоупотребление правом в уголовном судопроизводстве России» (О.И. Даровских).

Уголовно-процессуальная научная школа Южно-Уральского государственного университета, вклад в создание и развитие которой внес Юрий Данилович Лившиц, связана с исследованиями приоритетных проблем уголовно-процессуального права как теоретического, так и прикладного характера. Особое внимание уделяется актуальным проблемам использования специальных знаний в уголовном процессе, проблемам источников уголовно-процессуального права, вопросам разграничения компетенций эксперта и специалиста, особенностям получения, проверки и оценки доказательственной информации в уголовном процессе. Эти проблемы требуют постоянного научного осмысления в целях эффективной разработки предложений по совершенствованию норм права.

Юрий Данилович был не просто старшим другом и соратником, но и мудрым Учителем с большой буквы не только для своих многочисленных учеников, но и для всех нас. На его жизненном пути было много хороших людей, известных ученых и верных друзей, которые всегда поражались многогранному таланту профессора в совершенно различных сферах жизни, особому, уважительному отношению к людям, щедростью его души.

Заслуженный авторитет и любовь друзей и близких Юрий Данилович заработал честным трудом, и в том ему помогали высокое чувство долга, профессионализм, требовательность, прежде всего, к себе. При этом он не допускал подлости или обмана, был справедливым, порядочным, интеллигентным и очень скромным человеком.

\section{Библиография:}

1. Кудрявцева А.В. Значение научного наследия Ю.Д. Лифшица в развитии современного уголовнопроцессуального права // Актуальные проблемы права России и стран СНГ-2004 г.: Материалы VI Международной научно-практической конференции, посвященной 75-летию и памяти профессора Ю.Д. Лифшица. - 1-2 апреля 2004 г., - Челябинск, 2004. Ч. І. С. 121-123.

2. Лифшиц Ю.Д. Избранные труды. - Челябинск, Книга, 2004. - 216 с.

\section{References (transliterated):}

1. Kudryavtseva A.V. Znachenie nauchnogo naslediya Yu.D. Lifshitsa v razvitii sovremennogo ugolovnoprotsessual'nogo prava // Aktual'nye problemy prava Rossii i stran SNG-2004 g.: Materialy VI Mezhdunarodnoi nauchno-prakticheskoi konferentsii, posvyashchennoi 75-letiyu i pamyati professora Yu.D. Lifshitsa. - 1-2 aprelya 2004 g., - Chelyabinsk, 2004. Ch. I. S. 121-123.

2. Lifshits Yu.D. Izbrannye trudy. - Chelyabinsk, Kniga, 2004. - 216 s. 